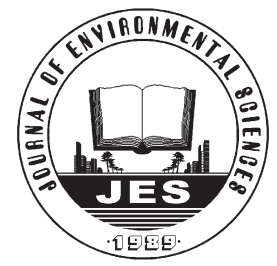

\title{
Arsenic uptake, accumulation and phytofiltration by duckweed (Spirodela polyrhiza L.)
}

\author{
Xin Zhang, Ying Hu, Yunxia Liu, Baodong Chen* \\ State key Laboratory of Urban and Regional Ecology, Research Center for Eco-Environmental Sciences, \\ Chinese Academy of Sciences, Beijing 100085, China
}

Received 28 May 2010; revised 14 July 2010; accepted 03 September 2010

\begin{abstract}
This study investigates arsenic (As) accumulation and tolerance of duckweed Spirodela polyrhiza L. and its potential for As phytofiltration. S. polyrhiza was able to survive in high concentration of $\mathrm{As}(\mathrm{V})$ solution. The $\mathrm{EC}_{50}$ values $( \pm \mathrm{SE})$ based on the external As $(V)$ were $(181.66 \pm 20.12) \mu \mathrm{mol} / \mathrm{L}$. It accumulated $(999 \pm 95) \mathrm{mg} \mathrm{As} / \mathrm{kg}$ dw when exposed in $320 \mu \mathrm{mol} / \mathrm{L}$ As(V) solution for one week, and was able to take up appropriately $400 \mathrm{mg} \mathrm{As} / \mathrm{kg} \mathrm{dw}$ in tissues without a significant biomass loss. The $\mathrm{EC}_{50}$ values (the effective concentration of $\mathrm{As}(\mathrm{V})$ in the nutrient solution that caused a 50\% inhibition on biomass production) was $(866 \pm 68) \mathrm{mg} / \mathrm{kg} \mathrm{dw}$ for the tissues, indicating that $S$. polyrhiza had a high capability of As accumulation and tolerance. The uptake kinetic parameters $V_{\max }$ was $(55.33 \pm 2.24) \mathrm{nmol} /(\mathrm{g} \mathrm{dw} \cdot \mathrm{min})$ and $K_{\mathrm{m}}$ was $(0.144 \pm 0.011) \mathrm{mmol} / \mathrm{L}$. Within $72 \mathrm{hr}, S$. polyrhiza decreased As concentration in the solution from 190 to $113 \mathrm{ng} / \mathrm{mL}$ with a removal rate of $41 \%$. The study suggested that this floating aquatic plant has some potential for As phytofiltration in contaminated water bodies or paddy soils.
\end{abstract}

Key words: arsenic; duckweed; phytofiltration; Spirodela polyrhiza L.

DOI: $10.1016 / \mathrm{S} 1001-0742(10) 60454-8$

Citation: Zhang X, Hu Y, Liu Y X, Chen B D, 2011. Arsenate uptake, accumulation and phytofiltration by duckweed (Spirodela polyrhiza L.). Journal of Environmental Sciences, 23(4): 601-606

\section{Introduction}

Arsenic (As) is a highly toxic and widespread environmental contaminant that poses hazards to humans. Groundwater contamination with As has led to serious health problems in many regions of the world such as Bangladesh, India and China (Mandal et al., 1997; Nickson et al., 1998; Chowdhury et al., 1999), in which millions of people suffer from As toxicity by drinking As-contaminated groundwater (Nordstrom, 2002). Contaminated groundwater is not only used for drinking purpose but also extensively used for irrigation. Long-term use of As-contaminated groundwater for irrigation has resulted in As elevation in paddy soil-rice system (Meharg and Rahman, 2003), which is posing a great health threat to rice subsistence populations globally via the food chain (Williams et al., 2007; Zhu et al., 2008).

Remediation methods are needed to mitigate As contamination in the rice production system. A potential remediation method should exploit for As accumulation by aquatic macrophytes which usually grow in water of paddy fields and ponds, and ultimately reduce As transfer to rice crop. To understand how macrophytes take up and metabolize As is important for the development of a new

\footnotetext{
* Corresponding author. E-mail: bdchen@ $@$ rcees.ac.cn
}

approach to mitigate the negative impact of As contamination. Recent studies have found that some species of aquatic macrophytes have moderate levels of As accumulation and tolerance. Zhang et al. (2008) have screened 50 strains of Azolla and found a large variation in As accumulation. Other studies have shown that some species of macrophytes could accumulate more than $1000 \mathrm{mg} \mathrm{As} / \mathrm{kg}$ dry weight by different mechanisms, including the New Zealand watercress (Lepidium sativum) (Robinson et al., 2003), Lemna gibba (duckweed) in tailing waters from two abandoned uranium mining sites (Mkandawire and Dudel, 2005), Egeria densa and Ceratophyllum demersum growing in the Waikato River system (Robinson et al., 1995) and a rootless duckweed Wolffia globosa (Zhang et al., 2009). Given the substantial capacity of macrophytes for As accumulation and tolerance, it may be possible to adopt these aquatic plants to reduce As concentration in water and paddy soil as a phytofiltration strategy. Mkandawire et al. (2004b) have conducted an experiment using synthetic tailing water and deduced that the potential extractions from surface waters with duckweed L. gibba was $751.9 \mathrm{~kg}$ As/(ha.yr) after desorption of surface complexed As with EDTA. Some other aquatic plants such as water hyacinth (Eichhornia crassipes), lesser duckweed (Lemna minor) (Alvarado et al., 2008) and a rootless duckweed (Zhang 
et al., 2009) have also been considered as promising candidates for phytofiltration in As contaminated water.

Spirodela polyrhiza L. is an aquatic plant floating in the ponds, lakes, ditches and rice fields in South Asian countries where As contaminated groundwater is used for irrigation during dry season. Owing to its wide distribution, high multiplication rates, short life span and easy to grow in the variable environments (Lemon et al., 2001), $S$. polyrhiza is regarded as an ideal biological material to investigate As metabolism and phytofiltration potential in macrophytes. Recent studies showed that As uptake in $S$. polyrhiza occurred through the phosphate uptake pathway and by physico-chemical adsorption on Fe-plaques of root surfaces as well (Rahman et al., 2008). The objectives of the present study were to investigate As accumulation and tolerance in S. polyrhiza, to determine the kinetics of $\mathrm{As}(\mathrm{V})$ uptake and to evaluate its potential for As phytofiltration.

\section{Materials and methods}

\subsection{Preparation of plant materials}

Duckweed S. polyrhiza was collected from ponds in Nanchang, Jiangxi Province, China. Plants were grown in hydroponic culture solution for 3 weeks before being used for experiments. The composition of the nutrient solution was as follows: $1 \mathrm{mmol} / \mathrm{L} \mathrm{CaSO}_{4}, 1.6 \mathrm{mmol} / \mathrm{L} \mathrm{MgSO}_{4}$, $0.3 \mathrm{mmol} / \mathrm{L} \quad \mathrm{KH}_{2} \mathrm{PO}_{4}, 0.3 \mathrm{mmol} / \mathrm{L} \mathrm{KCl}, 0.7 \mathrm{mmol} / \mathrm{L}$ $\mathrm{NaNO}_{3}, 10 \mu \mathrm{mol} / \mathrm{L} \mathrm{FeNa}$-EDTA, $20 \mu \mathrm{mol} / \mathrm{L} \mathrm{H}_{3} \mathrm{BO}_{3}$, and $7.7 \mu \mathrm{mol} / \mathrm{L} \mathrm{Na} \mathrm{NoO}_{4}$ (pH adjusted to 6.0 with $\mathrm{KOH}$ or $\mathrm{HCl}$ solutions). Nutrient solution was renewed twice every week. Experiments were carried out in a controlledenvironment growth chamber with 14-hr light/10-hr dark cycles. Temperature was kept at 25 and $20^{\circ} \mathrm{C}$ during day and night, respectively. Light intensity and relative humidity were maintained around $280 \mu \mathrm{mol} /\left(\mathrm{m}^{2} \cdot \mathrm{sec}\right)$ and $70 \%$, respectively.

\subsection{Kinetic of $\mathrm{As}(\mathrm{V})$ uptake}

Fresh S. polyrhiza plants were washed with de-ionized water and blotted dry. Four replicates of one gram of the duckweed were incubated in a test solution $(500 \mathrm{~mL})$ containing $5.0 \mathrm{mmol} / \mathrm{L} \mathrm{2-(N-morpholin)} \mathrm{ethansulfonic} \mathrm{acid}$ (MES) and $0.5 \mathrm{mmol} / \mathrm{L} \mathrm{Ca}\left(\mathrm{NO}_{3}\right)_{2}(\mathrm{pH} 5)$, with different concentrations of As(V) (0, 20, 40, 80, 160, 320 and 640 $\mu \mathrm{mol} / \mathrm{L})$. The solutions were shaken gently at $60 \mathrm{r} / \mathrm{min}$. After $20 \mathrm{~min}$, duckweed was collected and rinsed in an ice-cold phosphate buffer solution $\left(1 \mathrm{mmol} / \mathrm{L} \mathrm{K}_{2} \mathrm{HPO}_{4}, 5\right.$ $\mathrm{mmol} / \mathrm{L} \mathrm{MES}$ and $\left.0.5 \mathrm{mmol} / \mathrm{L} \mathrm{Ca}\left(\mathrm{NO}_{3}\right)_{2}\right)$ for $10 \mathrm{~min}$ to remove apoplastic As (Abedin et al., 2002). The tissues were then oven-dried for $48 \mathrm{hr}$ at $70^{\circ} \mathrm{C}$, sub-samples were digested and As concentrations were determined.

\subsection{Arsenate accumulation and tolerance}

After pre-cultured for one week, three grams of $S$. polyrhiza were cultured in a $500 \mathrm{~mL}$ conical flask containing $300 \mathrm{~mL}$ nutrient solution, covered with a membrane with small holes to minimize evaporation. The composi- tion of other nutrients was the same as in the preculture, except that the phosphate concentration was decreased to $0.1 \mathrm{mmol} / \mathrm{L}$. Seven concentrations of $\mathrm{As}(\mathrm{V})$ were used in this study $(0,10,20,40,80,160$ and $320 \mu \mathrm{mol} / \mathrm{L})$, each with four replicates. The conical flask were arranged randomly inside the growth chamber and re-arranged every day. The nutrient solution was renewed every three days. After seven days the plants were harvested, washed carefully with de-ionized water, blotted dry and fresh weight (fw) recorded. The samples were frozen in liquid nitrogen and freeze dried. The concentrations of total As and P were determined.

\subsection{Arsenic phytofiltration by $S$. polyrhiza}

After a 3-week preculture in hydroponics, S. polyrhiza was transferred to 5 - $\mathrm{L}$ plastic containers filled with 0.1 $\mathrm{mmol} / \mathrm{L} \mathrm{CaCl}_{2}$ solution for $12 \mathrm{hr}$. Three replicates (each of $10 \mathrm{~g}$ fw of $S$. polyrhiza) were then transferred to $1 \mathrm{~L}$ conical flask filled with $200 \mathrm{~mL}$ of $0.1 \mathrm{mmol} / \mathrm{L} \mathrm{CaCl}_{2}$ and 190 $\mu \mathrm{g} / \mathrm{L}(2.53 \mu \mathrm{mol} / \mathrm{L}) \mathrm{As}(\mathrm{V})$. A control without duckweed was included. The flasks were covered with a membrane with small holes to minimize evaporation. From each flask $2 \mathrm{~mL}$ solution was taken at 1, 6, 12, 24, 48 and $72 \mathrm{hr}$, and replaced with fresh $190 \mu \mathrm{g} / \mathrm{L} \mathrm{As}(\mathrm{V})$ solution. Total As concentration in the solution samples was determined.

\subsection{Plant tissue analysis}

Approximately $0.05 \mathrm{~g}$ dried plant material were weighed into $50 \mathrm{~mL}$ polypropylene digest tubes and steeped in 2 $\mathrm{mL}$ of high-purity nitric acid. The mixture was allowed to stand overnight at room temperature. Samples were randomized and then heated in a microwave-accelerated reaction system (CEM Microwave Technology Ltd., USA). The temperature was gently raised, first to $55^{\circ} \mathrm{C}$ and then to $75^{\circ} \mathrm{C}$ with holding time of $10 \mathrm{~min}$. Finally the digest was heated at $95^{\circ} \mathrm{C}$ for $30 \mathrm{~min}$ before reaching the room temperature. The digests were made up to a volume of 25 $\mathrm{mL}$ with ultrapure water $(18.2 \mathrm{M} \Omega)$. The concentrations of $\mathrm{P}$ in the digests were determined by inductively coupled plasma-optical emission spectrometer (ICP-OES, Optima 2000 DV, Perkin-Elmer, USA). Arsenic concentration was determined by atomic fluorescence spectrometry (AFS, AF-610A, Beijing Haiguang Analytical Instrument Co., China). A reagent blank and a certified reference material (bush twigs and leaves, GBW07603 from the National Research Center for Standard Materials in China) were included for quality assurance (Zhu et al., 2008).

\subsection{Data analysis}

All data were subjected to analysis of variance (ANOVA) using windows-based SPSS 13.0. The data of As(V) influx were fitted to a Michaelis-Menten equation using the SigmaPlot software (version 10) to estimate the maximum influx velocity $\left(V_{\max }\right)$ and $K_{\mathrm{m}}$ (Abedin et al., 2002).

\section{Results}

\subsection{As( V) influx kinetics}

As(V) influx into duckweed S. polyrhiza exhibited a 
hyperbolic pattern in relation to the increasing As concentrations in the incubation solutions (Fig. 1). As(V) influx kinetics was adequately described by the MichaelisMenten equation with $R^{2}$ value of $0.995(n=4)$. The kinetic parameters $V_{\max }( \pm \mathrm{SE})$ was $(55.33 \pm 2.24) \mathrm{nmol} /(\mathrm{g}$ $\mathrm{dw} \cdot \mathrm{min})$ and $K_{\mathrm{m}}( \pm \mathrm{SE})$ was $(0.144 \pm 0.011) \mathrm{mmol} / \mathrm{L}$.

\subsection{Arsenic accumulation and tolerance}

Increasing $\mathrm{As}(\mathrm{V})$ concentration in the nutrient solution decreased $(P<0.005)$ the growth of duckweed $S$. polyrhiza (Fig. 2). The dose-response data could be described satisfactorily by a log-logistic equation with $R^{2}$ value of 0.98 . Based on the fitted equations, the effective concentration of $\mathrm{As}(\mathrm{V})$ in the nutrient solution that caused a $50 \%$ inhibition on biomass production $\left(\mathrm{EC}_{50}\right)$ could be estimated. The $\mathrm{EC}_{50}$ values $( \pm \mathrm{SE})$ were $(181.66 \pm 20.12) \mu \mathrm{mol} / \mathrm{L}$.

Tissue As concentration significantly increased $(P<0.001)$ and exhibited a hyperbolic pattern in relation to the increasing concentration of $\mathrm{As}(\mathrm{V})$ in the incubation solutions. S. polyrhiza accumulated $(999 \pm 95) \mathrm{mg} \mathrm{As} / \mathrm{kg}$ $\mathrm{dw}$ in the $320 \mu \mathrm{mol} / \mathrm{L} \mathrm{As}(\mathrm{V})$ treatment after one-week

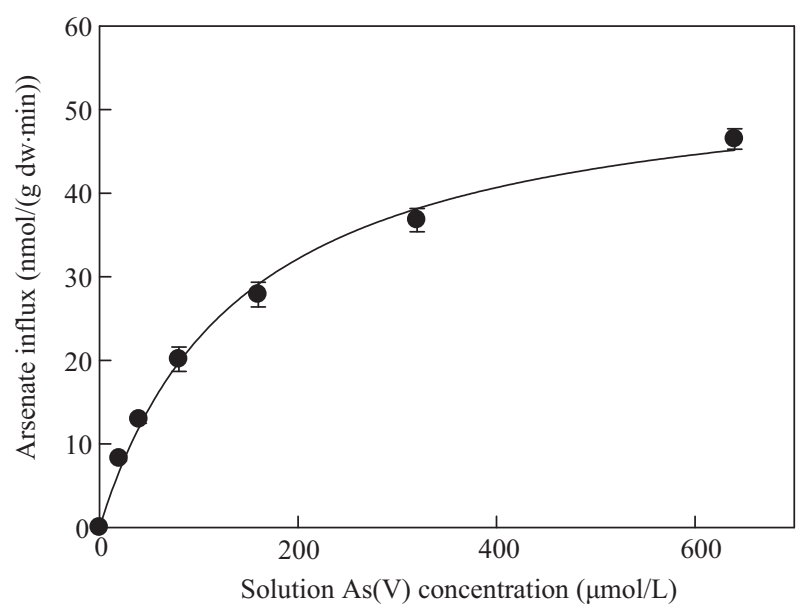

Fig. 1 Concentration-dependent kinetics for As(V) uptake by duckweed $S$. polyrhiza. Each point is represented as mean \pm SE $(n=4)$.

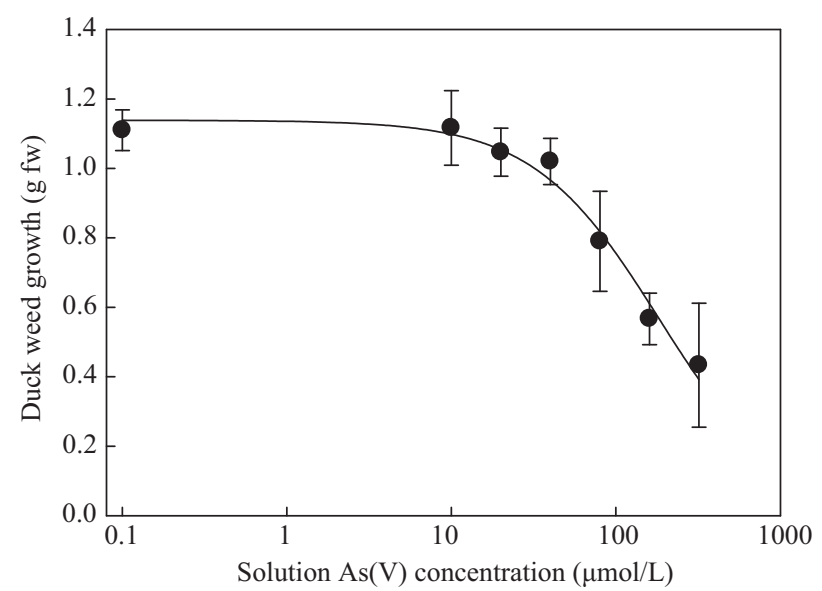

Fig. 2 Effect of As(V) exposure for one week on growth of duckweed $S$. polyrhiza. Data are mean \pm SE $(n=4)$. Lines are the fitted log-logistic curves. To allow log transformation, a small value $(0.1)$ was added to the zero As concentration in the control.
As(V) exposure (Fig. 3). To determine the $\mathrm{EC}_{50}$ values based on tissue As concentrations, the biomass data were plotted against tissue As concentration and the relationship was fitted with a log-logistic equation (Fig. $4 ; R^{2}=0.75$ ). The $\mathrm{EC}_{50}$ values $( \pm \mathrm{SE})$ were $(865.72 \pm 68.19) \mathrm{mg} / \mathrm{kg} \mathrm{dw}$.

\subsection{Phosphorus accumulation}

Tissue $\mathrm{P}$ concentration significantly decreased $(P<$ $0.001)$ and exhibited a hyperbolic pattern in relation to the increasing concentration of $\mathrm{As}(\mathrm{V})$ in the incubation solutions (Fig. 5). Regression analysis showed a negative correlation between tissue As and $\mathrm{P}$ concentrations with $R^{2}$ value of 0.77 (Fig. 6).

\subsection{Arsenic phytofiltration}

Within $72 \mathrm{hr}$, S. polyrhiza decreased total As concentration in the solution from 190 to $113 \mathrm{ng} / \mathrm{mL}$ (Fig. 7). The total As concentration in the solution exhibited a hyperbolic pattern within time. After that the duckweed became yellow and atrophied and there was no further decrease in

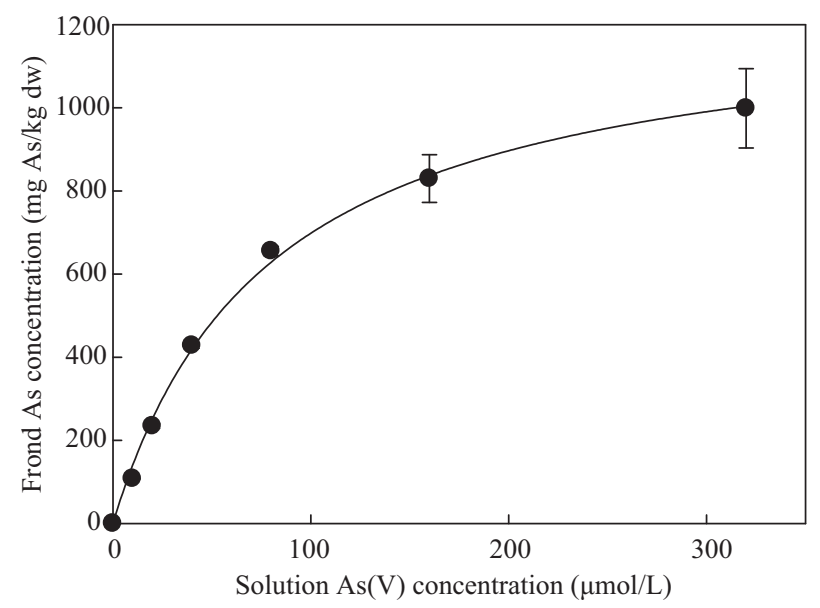

Fig. 3 Changes in tissue As concentration in duckweed S. polyrhiza grown in nutrient solutions with different $\mathrm{As}(\mathrm{V})$ concentrations for one week. Each point is represented as mean $\pm \operatorname{SE}(n=4)$.

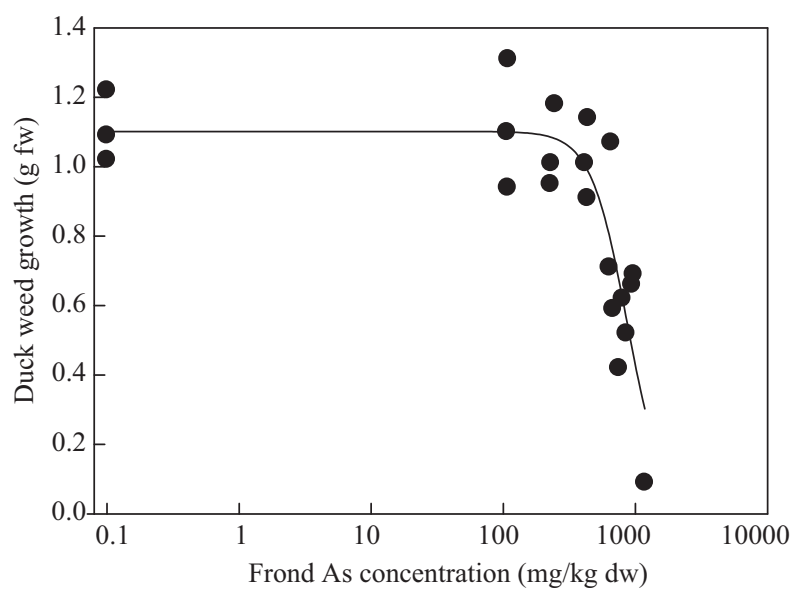

Fig. 4 Relationship between growth of duckweed $S$. polyrhiza and tissue As concentration after one-week exposure to different concentrations of As(V). Data are individual replicates. Lines are the fitted log-logistic curves. To allow log transformation, a small value $(0.1)$ was added to the zero As concentration in the control. 


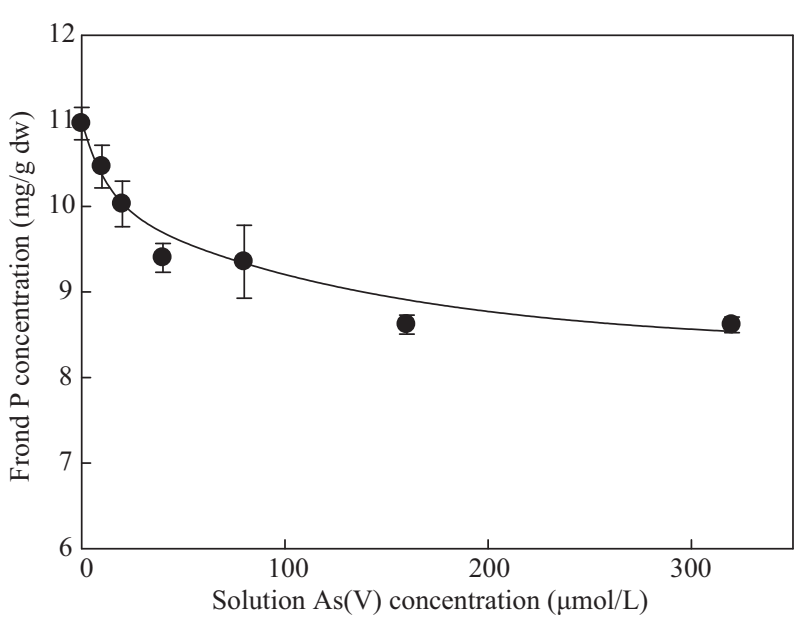

Fig. 5 Changes in $\mathrm{P}$ concentration in duckweed $S$. polyrhiza under different $\mathrm{As}(\mathrm{V})$ concentrations after plants had been supplied with As(V) for a week. Each point is represented as mean $\pm \operatorname{SE}(n=4)$.

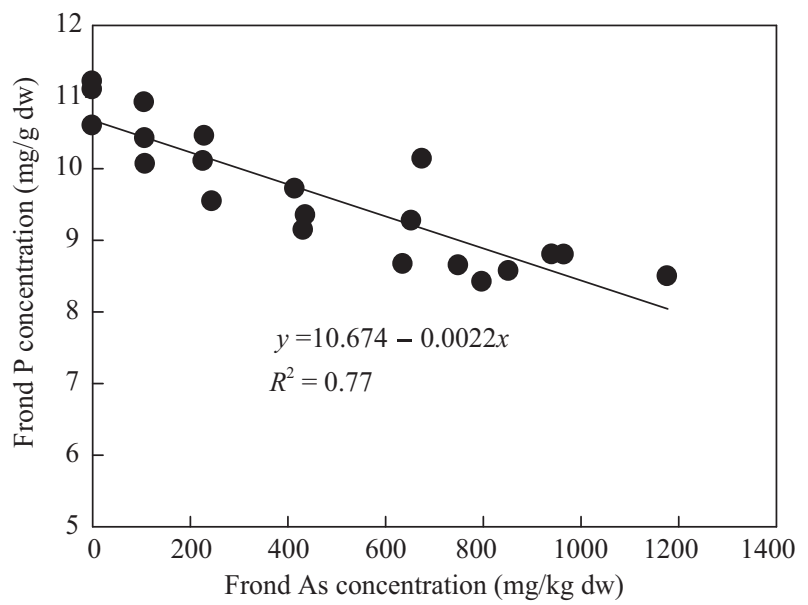

Fig. 6 Relationship between tissue As and $\mathrm{P}$ concentrations in duckweed $S$. polyrhiza after one-week exposure to different As(V) concentrations.

As concentration. While for the control without duckweed As concentration in the solution remained stable.

\section{Discussion}

In the short-term influx kinetic study, As(V) influx into $S$. polyrhiza followed the Michaelis-Menten equation. With regard to the kinetic parameters, the $V_{\max }$ value was the same as rice (Chen et al., 2005) and aquatic fern Azolla (Zhang et al., 2008), while the $K_{\mathrm{m}}$ value was $1-2$ orders of magnitude higher than those reported for rice (Abedin et al., 2002; Chen et al., 2005), Azolla (Zhang et al., 2008) and white lupin (Esteban et al., 2003). The $K_{\mathrm{m}}$ values could be comparable to those for a rootless duckweed W. globosa (Zhang et al., 2009) and for the arsenate-tolerant plant Holcus lanatus (Meharg and Macnair, 1992).

It has been documented that arsenate is taken up by plants via phosphate transporter systems because arsenate acts as a phosphate analog (Dixon, 1997). Most experiments demonstrated that arsenate inhibits phosphate uptake in yeast (Rothstein and Donovan, 1963), terrestrial plants such as wheat (Geng et al., 2006), the As hyperaccumulator, Chinese brake fern Pteris vittata (Wang et al., 2002), and macrophytes such as Azolla (Zhang et al.,

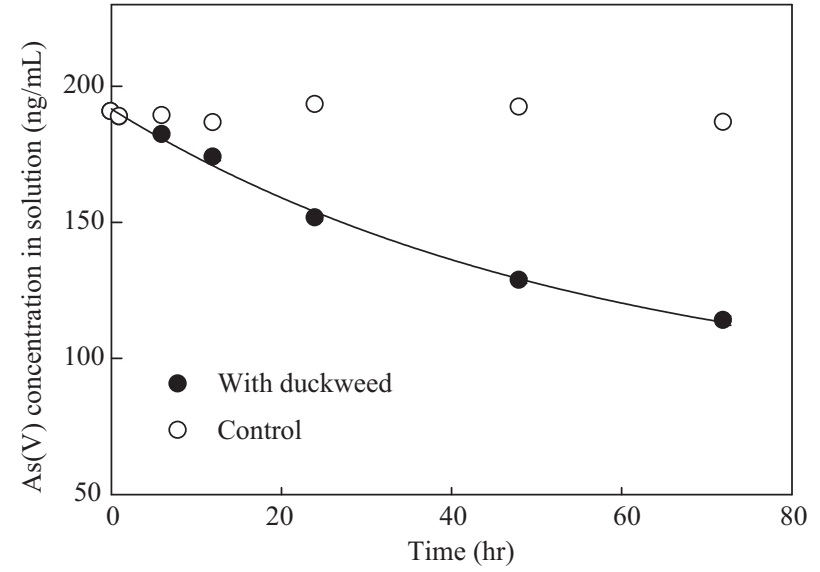

Fig. 7 Phytofiltration of As from water by 10 grams duckweed $S$. polyrhiza in $72 \mathrm{hr}$. The initial water contains $200 \mathrm{~mL}$ of $0.1 \mathrm{mmol} / \mathrm{L}$ $\mathrm{CaCl}_{2}$ and $190 \mathrm{ng} / \mathrm{mL} \mathrm{As}(\mathrm{V})$. Data are represented as mean $\pm \mathrm{SE}(n=$ 3 ). The control means the same treatment without $S$. polyrhiza. Data is represented as one replicate.

2008), duckweed L. gibba (Mkandawire et al., 2004a). In our experiment, the negative correlation between tissue As and $\mathrm{P}$ concentrations in S. polyrhiza also indicated that the $\mathrm{P}$ uptake in this aquatic macrophyte was inhibited by As(V).

S. polyrhiza was found to be able to survive in a high concentration of $\mathrm{As}(\mathrm{V})$ solution, indicating that this duckweed was tolerant to As. The $\mathrm{EC}_{50}$ values based on an external As(V) of S. polyrhiza was six times higher than that rootless duckweed W. globosa (Zhang et al., 2009). However, for the tissue As concentration S. polyrhiza accumulated $(107.6 \pm 0.6) \mathrm{mg} / \mathrm{kg} \mathrm{dw}$ incubating in 10 $\mu \mathrm{mol} / \mathrm{L}$ arsenate solution. The bioconcentration factor (BCF: the ratio of tissue As concentration to solution As concentration) was 142, which is four times lower than the rootless duckweed W. globosa exposed to the same As(V) concentration. It has been documented that a suppression of As accumulation is a mechanism for higher plants $H$. lanatus to achieve an enhanced resistance to external As(V), tolerant genotypes of H. lanatus accumulated As to a much less extent than non-tolerant plants (Meharg and Macnair, 1991). The results from the present study showed that $S$. polyrhiza enhanced resistance to external As(V) by reducing the As accumulation. The present study enriched this mechanism and proved that for macrophyte reducing As accumulation is also a way for improving tolerance to external As(V).

Unlike As non-hyperaccumulating species of higher plants, which usually appears As toxicity when tissue As concentration is above 10-100 mg/kg (Kabata-Pendias and Pendias, 1992). S. polyrhiza was able to accumulate appropriately $400 \mathrm{mg} \mathrm{As} / \mathrm{kg}$ in tissue dry weight (dw) without a significant biomass loss and the $\mathrm{EC}_{50}$ of the tissue As is about $(866 \pm 68) \mathrm{mg} / \mathrm{kg} \mathrm{dw}$. Our results indicated that $S$. polyrhiza had a higher ability of As accumulation and tolerance, which was higher than Azolla filiculoides and Azolla caroliniana (Zhang et al., 2008) and aquatic weed Hydrilla verticillata (Srivastava et al., 2007). Like S. polyrhiza, macrophytes L. gibba growing in mine tailing waters could also accumulate large amounts 
of As (Mkandawire and Dudel, 2005) and some aquatic species in Taupo Volcanic Zone, New Zealand had $>1000$ mg As/kg (Robinson et al., 2006), which indicated that some of the macrophytes have the capacity of higher arsenic accumulation. Such property opens up the possibility of selecting these macrophytes as ideal options of As phytoremediation. Recent studies have made great effort in developing cost-effective and eco-friendly As phytoremediation by using As hyperaccumulating ferns or macrophytes. Arsenic hyperaccumultor Pteris vittata and Pteris cretica were found to be very effective in removing As from the water to a level below the guideline value of $10 \mu \mathrm{g} / \mathrm{L}$ (Huang et al., 2004). Rootless duckweed W. globosa remove almost $50 \%$ of As in a hydroponic system (Zhang et al., 2009). Alvarado et al. (2008) also found the water hyacinth (E. crassipes) and lesser duckweed ( $L$. minor) had some potential for As bioremediation in waters. In the present study, by $S$. polyrhiza arsenic removal was $41 \%$, suggesting that phytofiltration by $S$. polyrhiza is a promising alternative for As removal from contaminated water or paddy soil.

\section{Conclusions}

The present study provides insights into the underlying mechanisms of As accumulation and resistance in $S$. polyrhiza, which had a high capacity of As accumulation and tolerance. This floating aquatic plant has some potential for As phytofiltration, and could be used as an alternative for As phytoremediation in contaminated water and paddy soil.

\section{Acknowledgments}

This work was supported by the Chinese Academy of Sciences (No. KZCX1-YW-06-03) and the National Natural Science Foundation of China (No. 20720102042).

\section{References}

Abedin M J, Feldmann J, Meharg A A, 2002. Uptake kinetics of arsenic species in rice plants. Plant Physiology, 128: 11201128.

Alvarado S, Guédez M, Lué-Merú M P, Nelson G, Alvaro A, Jesús A $\mathrm{C}$ et al., 2008. Arsenic removal from waters by bioremediation with the aquatic plants Water Hyacinth (Eichhornia crassipes) and Lesser Duckweed (Lemna minor). Bioresource Technology, 99: 8436-8440.

Chen Z, Zhu Y G, Liu W J, Meharg A A, 2005. Direct evidence showing the effect of root surface iron plaque on arsenite and arsenate uptake into rice (Oryza sativa) roots. New Phytologist, 165: 91-97.

Chowdhury T R, Basu G K, Mandal B K, Samanta G, Chowdhury U K, Chanda C R et al., 1999. Arsenic poisoning in the Ganges delta. Nature, 401: 545-546.

Dixon H B F, 1997. The biochemical action of arsenic acids especially as phosphate analogues. Advances in Inorganic Chemistry, 44: 191-227.

Esteban E, Carpena R O, Meharg A A, 2003. High-affinity phosphate/arsenate transport in white lupin (Lupinus albus) is relatively insensitive to phosphate status. New Phytologist,
158: 165-173.

Geng C N, Zhu Y G, Tong Y P, Smith S E, Smith F A, 2006. Arsenate (As) uptake by and distribution in two cultivars of winter wheat (Triticum aestivum L.). Chemosphere, 62: 608-615.

Huang J W, Poynton C Y, Kochian L V, Elless M P, 2004. Phytofiltration of arsenic from drinking water using arsenichyperaccumulating ferns. Environmental Science $\mathcal{E}$ Technology, 38: 3412-3417.

Kabata-Pendias A, Pendias H, 1992. Trace Elements in Soils and Plants. CRC Press, Boca Raton.

Lemon G D, Posluszny U, Husband B C, 2001. Potential and realized rates of vegetative reproduction in Spirodela polyrhiza, Lemna minor, and Wolffia borealis. Aquatic Botany, 70: 7987.

Mandal B K, Roy C T, Samanta G, Basu G K, Chowdhury P P, Chanda C R et al., 1997. In reply to "chronic arsenic toxicity in West Bengal". Current Science, 72: 114-117.

Meharg A A, Macnair M R, 1991. Uptake, accumulation and translocation of arsenate in arsenate-tolerant and nontolerant Holcus lanatus L. New Phytologist, 117: 225-231.

Meharg A A, Macnair M R, 1992. Suppression of the highaffinity phosphate uptake system: a mechanism of arsenate tolerance in Holcus lanatus L. Journal of Experimental Botany, 43: 519-524.

Meharg A A, Rahman M, 2003. Arsenic contamination of Bangladesh paddy field soils: Implications for rice contribution to arsenic consumption. Environmental Science $\mathcal{E}$ Technology, 37: 229-234.

Mkandawire M, Dudel E G, 2005. Accumulation of arsenic in Lemna gibba L. (duckweed) in tailing waters of two abandoned uranium mining sites in Saxony, Germany. Science of the Total Environment, 336: 81-89.

Mkandawire M, Lyubun Y V, Kosterin P V, Dudel E G, 2004a. Toxicity of arsenic species to Lemna gibba L. and the influence of phosphate on arsenic bioavailability. Environmental Toxicology, 19: 26-35.

Mkandawire M, Taubert B, Dudel E G, 2004b. Capacity of Lemna gibba L. (duckweed) for uranium and arsenic phytoremediation in mine tailing waters. International Journal of Phytoremediation, 6(4): 347-362.

Nickson R, McArthur J, Burgess W, Ahmed K M, Ravenscroft P, Rahman M, 1998. Arsenic poisoning in Bangladesh groundwater. Nature, 395: 338.

Nordstrom D K, 2002. Public health - Worldwide occurrences of arsenic in ground water. Science, 296: 2143-2145.

Rahmana M A, Hasegawaa H, Uedaa K, Makia T, Rahmanb M M, 2008. Arsenic uptake by aquatic macrophyte Spirodela polyrhiza L.: Interactions with phosphate and iron. Journal of Hazardous Materials, 160: 356-361.

Robinson B H, Brooks R R, Outred H A, Kirkman J H, 1995. The distribution and fate of arsenic in the Waikato River system, North Island, New Zealand. Chemical Speciation and Bioavailability, 7(3): 89-96.

Robinson B H, Duwig C, Bolan N S, Kannathasan M, Saravanan A, 2003. Uptake of arsenic by New Zealand watercress (Lepidium sativum). Science of the Total Environment, 301(1): 67-73.

Robinson B, Kim N, Marchetti M, Moni C, Schroeter L, Dijssel $\mathrm{C}$ et al., 2006. Arsenic hyperaccumulation by aquatic macrophytes in the Taupo Volcanic Zone, New Zealand. Environmental and Experimental Botany, 58: 206-215.

Rothstein A, Donovan K, 1963. Interactions of arsenate with the 
phosphate-transporting system of yeast. Journal of General Physiology, 46: 1075-1085.

Srivastava S, Mishra S, Tripathi R D, Dwivedi S, Trivedi P K, Tandon P K, 2007. Phytochelatins and antioxidant systems respond differentially during arsenite and arsenate stress in Hydrilla verticillata (L.f.) Royle. Environmental Science $\mathcal{E}$ Technology, 41: 2930-2936.

Wang J R, Zhao F J, Meharg A A, Raab A, Feldmann J, McGrath S P, 2002. Mechanisms of arsenic hyperaccumulation in Pteris vittata uptake kinetics, interactions with phosphate, and arsenic speciation. Plant Physiology, 130: 1552-1561.

Williams P N, Villada A, Deacon C, Raab A, Figuerola J, Green A J et al., 2007. Greatly enhanced arsenic shoot assimilation in rice leads to elevated grain levels compared to wheat and barley. Environmental Science E Technology, 41: 68546859.

Zhang X, Lin A J, Zhao F J, Xu G Z, Duan G L, Zhu Y G, 2008. Arsenic accumulation by the aquatic fern Azolla: Comparison of arsenate uptake, speciation and efflux by A. caroliniana and A. filiculoides. Environmental Pollution, 156: 1149-1155.

Zhang X, Zhao F J, Huang Q, Williams P N, Sun G X, Zhu Y G, 2009. Arsenic uptake and speciation in the rootless duckweed Wolffia globosa. New Phytologist, 182: 421-428.

Zhu Y G, Sun G X, Lei M, Teng M, Liu Y X, Chen N C et al., 2008. High percentage inorganic arsenic content of mining impacted and nonimpacted Chinese rice. Environmental Science E Technology, 42: 5008-5013. 